\title{
JOURNALISTS WANT VIRTUOUS PHYSICIANS? AN ANALYSIS BY THE MODEL OF ETHIC OF VIRTUES, IN REFERENCE TO BENEFICENCE, ACCORDING TO PELLEGRINO AND THOMASMA
}

\author{
Concília Ortona ${ }^{1}$, Paulo Fortes ${ }^{1}$
}

\begin{abstract}
A search of notes written by Brazilian journalists specialized in Health, representatives of major newspapers and magazines in the country, indicate that the main factor of Humanization of health care is the existence of virtuous physicians. They are capable of providing welfare and put patients' interests above their own. Therefore, health care based on Beneficence of patients. This draws attention, because it is a country where, in the field of bioethics, the model of Virtues, in the way it is taught by Edmund Pellegrino and David Thomasma, has been little studied. This also shows that autonomous attitudes of patients are poorly valued by respondents, but this may not mean yearning for paternalistic attitudes, but a benevolent attitude, recognizing the vulnerable condition in people who are sick.
\end{abstract}

Key words: bioethics, ethics, ethical theory, beneficence, journalism

¿Los periodistas quieren médicos virtuosos? Un análisis mediante el modelo de ética de las virtudes, en relación con la beneficencia, de acuerdo con Pellegrino y Thomasma

Resumen: Una búsqueda de noticias escritas por periodistas brasileños especializados en salud, representantes de los periódicos y revistas más importantes del país, indica que el factor principal de la humanización del cuidado de la salud es que existan médicos virtuosos. Médicos capaces de proporcionar bienestar y de poner los intereses de los pacientes por encima de los propios. Por tanto, cuidado de la salud basado en la beneficencia de los pacientes. Esto llama la atención, debido a que es un país donde, en el campo de la bioética, ha sido poco estudiado el modelo de las virtudes, en la forma enseñada por Edmund Pellegrino y David Thomasma. También muestra que las actitudes autónomas de los pacientes son poco valoradas por los participantes, pero esto puede que no signifique un anhelo de actitudes paternalistas, sino una actitud benevolente, reconociendo la condición vulnerable de las personas enfermas.

Palabras clave: bioética, ética, teoría ética, beneficencia, periodismo

Os jornalistas querem médicos virtuosos? Uma análise pelo modelo de Ética das Virtudes, e pelo referencial de Beneficência, de acordo com Pellegrino e Thomasma

Resumo: Pesquisa com jornalistas brasileiros especializados em Saúde, representantes dos principais jornais e revistas do país, indicam como principal fator de humanização dos cuidados de saúde a existência de médicos virtuosos e capazes de proporcionar bem-estar e colocar os interesses dos pacientes acima de seus próprios, ou seja, os cuidados de saúde com base na Beneficência dos pacientes. Isso chama a atenção, porque o Brasil é um país em que, no campo da bioética, tem pouco estudado o modelo das virtudes, na forma como é ensinado por Edmund Pellegrino e David Thomasma. Também mostra que as atitudes autônomas dos pacientes são pouco valorizadas pelos respondentes, mas isso pode náo significar o desejo de atitudes paternalistas e, sim, benevolentes, reconhecendo a condição de vulnerabilidade em pessoas que estáo doentes.

Palavras-chave: bioética, ética, teoria ética, beneficência, jornalismo

\footnotetext{
${ }^{1}$ Facultad de Salud Pública de la Universidad de São Paulo - FSP/USP, Brasil Correspondence: concilia42@hotmail.com
} 


\section{Introduction}

Amid the process of valorization of the technical-scientific Medicine, broad social professional categories, such as journalists, wants virtuous physicians and health care based on the patient's Beneficence, above all other interests and values (including the own autonomy of the patient), as provided by Ethic of Virtues crafted by the physician Edmund Pellegrino and the philosopher David Thomasma.

Such statements are derived from responses obtained in a study on "Humanization of Health Care" (1), made with journalists working in the field of Health in São Paulo, the most populous city Brazil ${ }^{2}$ and most influential in the global scenario in the country.

\section{Relevance}

The relevance and curiosity of the article, even for people outside of the context in which the research was conducted (São Paulo, Brazil), is verified by some facts: first, because Brazil is a growing Global nation, being the seventh largest mondial economy ${ }^{3}$ (estimated that, in 2016, become the fifth), surpassing the U.S. ranking on "the influence of the world"4.

The population of physicians, whose ethical behavior is the target of much of the work of Pellegrino and Thomasma, achieves considerable numbers in the state of São Paulo: total approximately 160.000 enrolled in the largest state medical association ${ }^{5}$ being about 114.000 in activity.

Furthermore, the social importance of the research subjects, journalists, is evidenced by the scope of the publications in which they operate: aggregate, daily newspapers chosen for the survey sample have an average circulation of $715.000^{6}$. Weeklies chosen reach 1,207 million ${ }^{7}$. As trendsetters that they are, it seems appropriate to con-

\footnotetext{
${ }^{2}$ Estimated population in 2012. Brazilian Institute of Geography and Statistics (IBGE).

${ }^{3}$ World Economic Outlook - FMI.

${ }^{4}$ Study 2011 BBC / GlobeScan / PIPA.

${ }^{5}$ Regional Council of Medicine of São Paulo, May 2013.

${ }^{6}$ The National Newspaper Association, ANJ, 2011.

${ }^{7}$ Circulation Verification Institute, 2008.
}

sider that their texts influence, in varying degrees, the thought of a number of readers.

Finally, we intend to spread some of the work of Pellegrino and Thomasma and show that the content of the answers of respondents is consistent with the model worked out by these authors, who bring in their curricula facts like driving the Kennedy Institute of Ethics and chairing the Council U.S. presidential Bioethics, in the case of Pellegrino, and establish the journal Cambridge Quarterly of Healthcare Ethics, as did Thomasma.

It is noteworthy that, in thirty years of Bioethics in Brazil, the authors seem little studied and known in a country that, since the beginning, has prioritized the model "principialist" represented by Tom Beauchamp and James Childress: just to give an idea, no books of Pellegrino and Thomasma about Ethics of Virtues was launched in the country, in Portuguese, even For the Patient's Good: Toward the Restoration of Beneficence in Health Care, 1988, and Virtues in Medical Practice, 1993, seen as global references in the Bioethics universe.

\section{$A$ little on the virtues}

The contemporary Ethics of Virtues has as its most prominent representatives Edmund Pellegrino of Georgetown University (died June 2013), and David C. Thomasma, Loyola University, Chicago, (died 2002), who worked with the model since the 1980s.

To substantiate their theories as applied to the practice of the virtues of the health professions, in particular, of Medicine, the authors wrote together texts devoted to the philosophy of medicine leading some ethics and bioethics specialists $(2,3)$ consider that Pellegrino and Thomasma interest is expressly for medical ethics and not by Bioethics, in its widest sense.

For Pellegrino and Thomasma, the definitions of "virtues", and about that is a virtuous person, occupy philosophers since Plato raised the issue.

The history of the concept of "virtue", however, can be divided into four seasons(4): 1) the classical-medieval period, when the virtues formed the 
basis of all moral philosophies, following in particular the thought of Aristotle; 2) post-medieval and modern, in which Ethics based on Virtues continued to be important, but open space for new systems of moral philosophy; 3) Analyticalpositivist, that noted the decline of Ethics of Virtues, and the supremacy of traditional normative ethics; 4) period current, which show up the return of relevance of Virtues as basis of morality.

To reach their own conclusions, Pellegrino and Thomasma followed the line of other contemporary philosophers, like Alasdair MacIntyre (looking, like him, reasoning on philosophical roots based on the teachings of Aristotle and St. Thomas Aquinas), and their own Catholic roots. "Despite several attempts, no one has brought down the definition by Aristotle", that identifies the moral virtues as character states that determine whether we act good or evil, according to our passions(5).

From the point of view of the authors(6), the model of the virtues can be summarized in "firm measures to act well in any act that is involved in trying to achieve a certain end." For them(7) a virtuous person is someone others can trust, who is brave, honest, modest, and remains in search of perfection, both in personal and professional life. Is someone going to do well, although there are no others to applaud, simply because, on the contrary, would violate what is a "good human being".

As mentioned, the emphasis of Pellegrino and Thomasma work back to the nature of the doctorpatient relationship, as well as its role within the core goals of medicine and the care of the human being. Ie doctors and health professionals - who sometimes have difficulty returning the value of virtue(8)-, integrating the decision process of the patient.

As once said Pellegrino(9), all the problems of human life -the alienation, the affection, the social and cultural relations, and even salvation- intensify in "existential laboratories", known as "hospitals". In this scenario, each humanistic question assumes larger size, when embedded in concrete situations, such as "ease the pain or not," or "limited or no treatments in desperate situations."
The virtues in the relationship with patients, according to Pellegrino and Thomasma(6), result of the encounter that makes the medicine being what it is and distinguishes it as a "kind of special activity, in which the rights of the physician sometimes are exceeded by strength of the bond established with the ill person".

For a doctor who base his behavior on virtues, the relationship with a patient shall not be a commercial contract: rules are based on trust, ie, in his or her special vocation to serve those who seek their expertise. So he or she will never consider a patient as a "customer" or be motivated by commercial transactions, industrial, etc.

A virtuous physician, without doubt, must be a "virtuous person"(7), striving to fulfill their job with excellence and striving to do it the best way possible, bringing the patient above their own interests, without serve the vulnerability of sick person to increase their own power, prestige and money. Therefore, medical training should aggregate the medical science of the human with what is to be a good human that is "the true good for humans"(10).

Some identify be the relationship of "trust" what makes the clinical medicine more than just a science, art or profession(11), because it is through it that the virtuous professional establish as a goal attitudes as "to heal when possible, to care always, alleviate suffering and cultivate health". Remembering: patients are almost "forced" to rely on physicians(4) due to their condition "vulnerability, dependency, anxiety and limitation of freedom caused by the disease."

\section{A little about the beneficence, according to Pellegrino}

Pellegrino and Thomasma elect as the main principle of the ethical context Benevolence (wish the good). In the context of ethics, value the Beneficence (act for the good), especially in relationships between health professionals and patients, as the authors believe that the models of autonomy and paternalism have more limitations and shortcomings of the Beneficence(6).

Indeed, they consider the concepts of "Benevolence" (or "Beneficence") and what is it is "a vir- 
tuous professional" are often linked, because the former is a primary requisite to the second.

In their view, many doctors say that the appreciation of Beneficence of the patient, rather their own Beneficence, is questionable, or even reprehensible, since, like all others, doctors have the right to recreation, to family life, the social activity, the absence from work, strike, and the freedom to treat only those who pay.

These may not be overtly unethical practices in the opinion of Pellegrino and Thomasma(7), but "are often on the border of moral, while the self-giving would dictate some limits to their own interests."

When observing the method presented by Edmund Pellegrino, ie beneficence based on trust, it is observed that this involves both clinical and personal(12) issues, as the good of patient can only be achieved when according to his or her best interests, which involves personal choices, culture and religion, among others.

Remember that, by "trust" Pellegrino refers not to trust in the "infallibility" of the professional, but in the belief that the physician will act according his or her proposes, ie, according to the "best interests of the patient"(12).

A physician guided by Beneficence, finally, is one that, somehow, is able to meet the expectations of their patients(13), since the "promise to save the patient raises in him or her the hope that the professional has the competence and expertise necessary for his or her case."

\section{Method}

The article presented here was based on responses from interviews(1) performed during the first seven months of 2009 , with 15 journalists who work in Health -either uniquely or eventuallybetween reporters, editors and assignment editors (professionals within an essay, have the task of deciding what will be reported) in the press of São Paulo, in publications that circulate nationally in Brazil.

We had the participation of two representatives from each of the following newspapers, quite significant in the Brazilian context: Agora São Paulo,
Diário de São Paulo; Folha de São Paulo, O Estado de Sáo Paulo, and of the magazines Carta Capital; Época; Isto é, and Veja São Paulo (where, exceptionally we talk with just one journalist). All newspapers and magazines chosen, directly or indirectly, bring specific information geared to the theme "Health", and the majority has editorials in Health. When this is not the situation, the topic "Health" is addressed in other editorials, but always by journalists.

For the selection of the newspapers, we chose those destined from the so-called "popular" readers, targeted at an audience with educational trajectory below the university level, to others, destined to a reader who has higher cultural level, in university or post-graduation.

The choice by the magazines of general information of São Paulo, but with national reach, was mainly because each of them reaches people divergent political trends. That means sought to be inclusive and representative in the Brazilian context.

The interviews were conducted in person, in the workplaces of journalists, and lasted on average one hour. Were included, among others, questions involving knowledge and the way they approach the humanization and dehumanization in health care and in respect of humanized and dehumanized treatments.

Although the focus of the interviews - the humanization of health care - was just related to the theme of Bioethics, we identified that the content of the responses is quite connected to thinking of Pellegrino and Thomasma on the Ethics of Virtues.

According Pellegrino(14), in its early stage, in 1960, the Bioethics emerged of "perception of the dehumanization of medicine, due to the power of science and technology."

By the late 1970s, he explains, the term "Bioethics" gradually begins "encompass the movement of the humanization of medicine (...) and also embracing human values, humanities and medical ethics". 


\section{For the good of the patient}

First observation: in the opinion of the majority of respondents, health care that respect humanity shall to be seen as a process, whose purpose is to provide comfort to the patient, and to act "for the good of the patient", as purposed by Thomasma and Pellegrino(7).

This vision of "good", "well-being" and "Beneficence" directed to the patient, that include attitudes that go beyond the simple treatment, is observed in the opinions of the participants, who referred to the Humanization as a process, whose purpose is to provide the welfare to all present in the context of health care, ie, patients, families and employees.

In their responses, for example, research subjects have cited cases of terminally ill patients, who need to "feel good and welcomed" and never "to suffer unnecessarily" and opined that the comfort and care that go beyond the healthcare setting "contributes to a positive evolution of the disease".

For participants, when we talk about "welfare", we are including details, such as permission, by doctors and other health professionals, of the presence of family members in the treatments room and ER, especially when the patient is emotionally vulnerable. It also involves the comfort provided by health professionals, as can be seen in the statements summarized below:

Why the doctor sometimes refuses that your patient had the company of someone in your family, in the ward? Why only patients over 65 years old may have a companion? There are others with even greater weakness, more afraid, and they are forced to be alone. Why the health professional does not arrive at that old man, who is there, alone, waiting to go through chemotherapy, and shows interest for his welfare, trying to tell him a joke, talking about football?(1).

Besides only its benevolent action, in Pellegrino's(15) opinion, the doctor, actually, should somehow returning to society the help he got during his or her training. "The doctors receive their training and knowledge and develop their skills as a result of an agreement with society. To them is allowed dissect corpses, make research with humans, perform physical examinations, autopsies, assist in the care of patients, set practical procedures and even seek knowledge about the emotional and private life of patients, resources only allowed because of the profession will perform".

The society allows inexperienced people to gain skill and practice in that way. Doctors, in turn, receive benefits by using the skills learned. In fact, there is an implicit agreement when students begin their medical studies(15). In return for what they were allowed to learn, they should care for those who need their skills.

In the opinion of respondents, agreeing with Pellegrino and Thomasma, the physician is the central figure in the gear of a health care, if the intention is to provide well-being for the ill person. "Medicine does not relate simply to a technically proficient performance, but the way this is used to achieve the expected result, the good of a human person with spiritual destiny, if that is your belief"(9).

What disease does to the sick person, breaking bonds and certainties, requires of doctor a degree of kindness that goes beyond non-maleficence passive. It includes some obligation to act in the interest of the patient, even if it costs his own comfort, power and prestige(9).

This health care professional, able to act beyond their obligations, is also what journalists want. Speeches as set below were frequent:

I did an article on patients with severe physical impairments andlor mental disabilities, whose families are unable to provide care. Some had the chance to go for a walk connected to a ventilator, with the whole apparatus, with the hospital's medical team. This is "to be a doctor"(1).

I was delighted, in a hospital, the loving way that doctors and nurses dealing with premature tiny babies, trying to avoid their pain and minimize the consequences in the future(1).

The doctor and other professionals should be aware of other issues, like pay attention if the companion of 
the ill person has money to pay for his own food, has sleeping conditions...(1).

\section{List of virtues}

In his work, Pellegrino and Thomasma developed a list of virtues(16) of a medical act, ie, "excellences of character required for the practice of medicine, in particular, and the health professions in general."

They are: Fidelity to Promise (answer of what assured to the patient, from the trust established by the bond physician-patient); Benevolence (seek the integral good of the patient); Abnegation (go beyond their own interests, fighting for the dignity of the patient and for overcoming structural failure of the institutions); Compassion (empathy and habitual disposition to understand the uniqueness of each patient and the specific situation); Intellectual Humility (share information, recognize the limits of their knowledge and admit ignorance, when you do not know).

Also includes Justice (the professional needs to adjust to the specific needs of each patient, even when these exceed what is owed); Prudence (should be evaluated all possibilities. Prudence does not guarantee that the decision is more correct, however, guarantee what is more reasonable).

Of the 15 journalists surveyed, 13 agree with Pellegrino and Thomasma, to wish (and to consider that the general population also wishes) that the physician be virtuous, demonstrating qualities of character, such as: moral virtues and intellectual virtues. Want physicians faithful to their own promises, benevolent, selfless and compassionate.

From the point of view of the patient, a good physician is the one who will examine, ordering tests and solve his or her problem: you have a little doctor who is there to spend a little prescription and heal (Fidelity to Promise)(1).

The doctor should know that the patient is in a very vulnerable state and think about it in the moment of deal with him (Benevolence)(1).

You may even be in a hospital with poor structure, but if you count professional attentive to the issue of humanization, involved with what they are doing, the problems are minor (Abnegation)(1).

Human is a physician who sees the patient as an equal. There is not the thing of to say: "I'm the doctor, the patient is downstairs." Needs to see the patient, be trained to look the other way, to understand another's pain... (Compassion)(1).

Furthermore, the participants consider that professionals need to demonstrate intellectually humble, fair and prudent.

The principle of humanization is to get an accessible dialog between doctor and patient. It is the base. So, I explain to my reader that the doctor should admit when they have no answers about treatments (Intellectual Humility)(1).

Sometimes the patient gets lost with too many details, but do not do any question, because he is ashamed: he thinks the doctor is in the pinnacle, which can not be questioned. (Intellectual Humility)(1).

I do not think a doctor in a public hospital is worse than in a private hospital: the first may even be better, because it needs to handle more patients without having so many advances, which will give to the doctor more conditions to find new solutions (Justice)(1).

The good professional should be attentive to details and relate them to the patient's condition. It is a professional who looks at you, asks your name, your story, the way you relate to your family, devotes at least half an hour of attention (Prudence)(1).

\section{Patient autonomy}

Despite electing the principle of Beneficence as the most important ethical principle in medical context - surpassing the other two dominant in the field of contemporary medical ethics, which are the Autonomy of the individual and the Social Utility, above the individual autonomy(7) - in Pellegrino's opinion (5), Autonomy can not be considered as a secondary principle. "Violating the autonomy of someone is violating the dignity of the human being." That is, if the patient make a free decision, valid and without coercion about not using a treatment in particular, it must be respected. 
For Pellegrino (17) autonomy is a reciprocal moral claim: the physician must not violate the moral right of the patient to refuse treatment recommended. But the moral right of the patient to their own autonomy do not includes postulate his or her treatment or micromanagement of their own treatment."When they disagree, they should stop their relationship without rancor."

At the beginning of this work, it was thought that, between the interviewed journalists, would be emphasized the respect for autonomy, which, according to Pellegrino and Thomasma (7), is "one of the most valued principles of contemporary ethics." That point of view would also agree with autonomy so widespread in the country, based on the teachings of Beauchamp and Childress.

However, instead, the patient's autonomy in the field of hospitals and clinics was rarely mentioned. Only one respondent directed his speech to such an approach, reporting on the article made shared decision health.
So here is a question that still needs to be answered through specific studies and in-depth: the media professionals of São Paulo (and other major cities of the world) wish that doctors and other health professionals had paternalistic attitudes towards the patient?

\section{Conclusions}

Respondents consider physicians essential to provide well-being of the patient; desiring a virtuous professional, as suggested by Pellegrino and Thomasma, that is, able to put patients' interests ahead of their own. However, the research do not pointed patient autonomy as being important in the context of health care, but it might not mean yearning for paternalistic attitudes and yes, benevolent, recognizing the vulnerable condition in which they are sick. 


\section{References}

1. Ortona C, Fortes PAC. Perception of representatives of the written press in Säo Paulo about the Humanization of Health Services (online). Master's Dissertation (Accessed: November 9, 2012). Available in http://www.teses.usp.br/teses/ disponiveis/6/6135/tde-13102010-092806/pt-br.php

2. Engelhardt H, Jotterand F, (eds.) The Philosophy of Medicine Reborn: A Pellegrino Reader. Indiana, US: University of Notre Dame Press; 2008.

3. Ferrer JJ, Álvarez JC, (eds.) El paradigma de las virtudes. Para fundamentar la bioética: Teorías y paradigmas teóricos en la bioética contemporanea. Madrid: Pontificia Universidad Comillas; 2003.

4. Cruz J, Edmund D. Pellegrino: the doyen of global bioethics. Rev Portuguese of Bioethics 2010; 11: 173-190.

5. Pellegrino ED, Thomasma DC. The christian virtues in medical practice. Washington: Georgetow University Press; 1996.

6. Ortona C. The welfare of the patient must outweigh the interests of the physician. Rev Ser Médico, Regional Medical Council of the State of São Paulo 2011; 56: 4-8.

7. Pellegrino ED, Thomasma DC. For the patient's good: the restoration of beneficence of the healing professions. New York: Oxford University Press; 1988

8. De P. de Barchifontaine Ch, Pessini L. Bioethics: some aspects of its genesis and its development. In: Pessini L, Barchifontaine, CP, authors. Current issues of bioethics. São Paulo: Loyola; 2012.

9. Beeman PC. First things: the philosophy of Medicine Reborn. 2008. (online). (Accessed on: May 23, 2013). Available in: http://www.firstthings.com/onthesquare/2008/05/the-philosophy-of-medicine-reb

10. Giordano J. Foni phoronimos - an interview with Edmund D. Pellegrino. Rev PEHM philosophy, ethics and humanities in medicine 2010; 5. (on-line). (Acessado em: 22 maio 2013). Disponível em: http://www.peh-med.com/content/5/1/16

11. Pellegrino E. Professionalism, profession and virtues of the good physician. Mount Sinai Journal of Medicine 2002; 6(6): 378-384

12. Rocha DM. The philosophy of medicine by Edmund Pellegrino and bioethical dilemmas related to assisted suicide. Rev Bioética, Federal Council of Medicine of Brazil (CFM) 2013; 21: 75-83.

13. Pellegrino ED, Thomasma DC. La medicina por vocación. Quito: Ediciones Camilianas; 1995.

14. Pellegrino ED. Origin and evolution of Bioethics: a personal view. Kennedy Institute of Ethics Journal 1999; 9(1): 73-88.

15. Pellegrino ED. Allocation of resources at the bedside: the intersections of economics, law and ethics. Kennedy Institute of Ethics Journal 1994; 4(4): 309-317.

16. Pellegrino ED. Toward a virtue-based normative ethics for the health professions. Kennedy Institute of Ethics Journal 1995; 5(3): 253-77.

17. Cruz J. Bioethics and virtue ethics: an interview with dr. Edmund D. Pellegrino. Rev Bioética Latinoamericana 2012; 10: 46-52.

Received: September 23, 2013

Accepted: November 18, 2013 